\title{
Assembling agroecological socio-natures: a political ecology analysis of urban and peri-urban agriculture in Rosario, Argentina
}

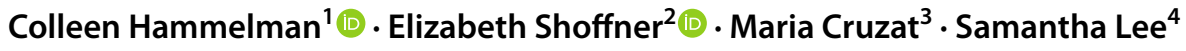

Accepted: 15 July 2021 / Published online: 24 July 2021

(c) The Author(s), under exclusive licence to Springer Nature B.V. 2021

\begin{abstract}
Rosario, Argentina, a city of more than one million people strategically located on the Paraná River in the heart of a fertile agricultural region, is home to a significant industrial corridor where ongoing urbanization for industry, including that associated with the port complex and agroexport industries, vies for real estate space with peri-urban and urban farming production. The city is also the site of thriving municipal programs seeking to change food production and consumption outcomes through urban and peri-urban agriculture projects rooted in agroecology. This paper identifies the socio-natures critical for the formation and endurance of these agroecology assemblages. Based on interviews with 30 stakeholders in government, civil society, and agricultural production, we describe the integrated approach to environmental, social, and economic sustainability embedded in Rosario's institutional agroecology programs. In particular, we discuss the actors and strategies (which seek to preserve land for agricultural uses), discursive renderings of socio-natures (as valuable biodiverse territories and productive diverse bodies), and the marketing of agroecological materialities (through production for public markets) that form and are formed by these assemblages. We also discuss the power dynamics embedded in sustaining urban and peri-urban agroecological projects through institutional means. This research contributes to literature on agroecology, urban agriculture, and the urban metabolism through providing empirical examples of socio-natural entanglements in urban agroecological assemblages.
\end{abstract}

Keywords Agroecology · Argentina · Assemblages · Urban political ecology

Colleen Hammelman

colleen.hammelman@uncc.edu

Elizabeth Shoffner

esho@uw.edu

Maria Cruzat

mcruzat@uncc.edu

Samantha Lee

slee206@uncc.edu

1 Department of Geography and Earth Sciences, University of North Carolina at Charlotte, 9201 University City Blvd, Charlotte, NC 28223, USA

2 Department of Geography, University of Washington, Smith Hall 408, Box 353550, Seattle, WA 98195, USA

3 Public Health, International Studies, and Spanish, University of North Carolina at Charlotte, 9201 University City Blvd, Charlotte, NC 28223, USA

4 International Studies and Spanish, University of North Carolina at Charlotte, 9201 University City Blvd, Charlotte, NC 28223, USA

\author{
Abbreviations \\ INTA National Institute of Agricultural Technology in \\ Argentina \\ PAU Programa de Agricultura Urbana (Urban Agricul- \\ ture Program), Municipalidad de Rosario \\ UA Urban agriculture \\ UPE Urban political ecology
}

\section{Introduction}

Urban agriculture needs to be transversal. It should be present in all policies: social policies, healthcare and culture because it rescues food (urban agricultural producer and advocate in Rosario, Argentina, 2019). Before we called it "weeds," I don't like to call it weeds, us humans are the weeds, it's vegetative biodiversity (peri-urban, agroecological farmer in Rosario, Argentina, 2019). 
The municipal government in Rosario, Argentina, has supported agroecological food production for nearly 20 years. Often held up as an exemplary model of urban agriculture practice (FAO 2014) and studied by practitioners worldwide (Santandreu et al. 2009; Suzuki 2012, among others), the city has been at the forefront of promoting agroecology in urban and peri-urban systems, creating markets for marginalized agroecological producers, and recognizing the integration of environmental, economic, and social strategies for improving food systems. The city's Urban Agriculture Program (PAU) is a long-standing urban agroecological intervention of the municipal government, while the more recent Greenbelt Project incorporates peri-urban agriculture. As the quotes above from research participants ${ }^{1}$ indicate, many urban agriculture (UA) advocates and practitioners in Rosario recognize both the expansive reach of UA and the divides it bridges between society and nature.

Responding to Classens' (2015) call to better theorize nature in urban gardens, we contribute to literature on agroecology, UA, and the urban metabolism through providing empirical examples of socio-natural entanglements in urban agroecological assemblages. By conceptualizing the institutional agroecology programs, growers, land, discourses, and materials as assemblages, we highlight the complex and contingent qualities of urban and peri-urban socio-natures that contribute to Rosario's urban metabolism. These assemblages complicate two key tensions of urban agroecological praxis. First, frameworks of political agroecology have often ignored urban spaces as sites of political intervention, due to perceptions of their limited productive scope (Altieri et al. 1999; Altieri and Nicholls 2018 provide notable exceptions). Second, when UA is promoted by institutions, it is often critiqued (or dismissed) as cooptation (Giraldo and Rosset 2018) or evidence of neoliberalization (Rosol 2010). Our case study of institutional urban and peri-urban agriculture in Rosario instead demonstrates the complex agroecological socio-natures successfully constituted through these interventions often framed as productively, politically, and socially unviable.

This paper begins with a discussion of the theoretical lens we utilize to examine these two programs as interrelated, yet distinct, agroecological assemblages contributing to the urban metabolism. We then trace the ways they produce particular socio-natures through claiming territory for agricultural purposes, making visible embodied productive labor, and marketing agroecological materials. We examine the strategies and discourses mobilized by assembled spaces, bodies, and institutional actors. Finally, we discuss the power dynamics embedded in sustaining urban and periurban agroecological projects through institutional means.

\footnotetext{
${ }^{1}$ All direct quotes have been translated from Spanish by the authors.
}

\section{Agroecology and assemblage-thinking in Latin America}

Long-standing practices of ecological agriculture by many Indigenous and campesino farmers in Latin America-and their resistance to the expansion and intensification of industrial agriculture-provided the basis for the institutionalized and technical agroecology that became more visible in the 1980s and 1990s (Sevilla Guzmán 2015). Perceived as more knowledge-intensive and less resource-intensive than industrial agriculture (Anderson et al. 2018; Marchetti et al. 2020), agroecology takes a bottom-up approach, relying on the knowledge and natural resources of local communities for agricultural production (Altieri and Nicholls 2018). Agroecology is increasingly recognized as a foundation for transforming entire agrifood systems, through reconciling environmental, economic, and social dimensions of sustainability (Gliessman 2020). Grounded in the social justice frameworks of agrarian social movements, agroecology moves beyond the perspectives of non-governmental and academic development (Dale 2020). Prioritizing the interrelationships between people, farming, and nature, and increasing the autonomy of farmers by recognizing their knowledge and local resources, agroecology is considered inseparable from social movements, particularly for food sovereignty (Anderson et al. 2018). Toledo (2011) characterizes this as the tridimensional nature of agroecology: as a science, an embodied and innovative agricultural practice, and a grassroots socio-political movement of small producers.

Movements pursuing agroecology argue that viewing agricultural systems in terms of commodity production fails to recognize the efficiencies and outputs of small farms. Instead, agroecology practitioners emphasize its grounding in the ecology of traditional agricultural and the sociocultural needs of rural communities (Marchetti et al. 2020). In agroecological systems, farmers are given more credit as ecological stewards of food systems (Isaac et al. 2018). Agroecology, as science, practice, and movement, encompasses the ecological, economic, and social dimensions ${ }^{2}$ of food systems (Francis et al. 2003; Isaac et al. 2018) and values the ways ecology can inform and guide their management and design (Gliessman 2007). In contrast to some approaches to organic agriculture, agroecology pursues a better understanding of how nature works, replicates

\footnotetext{
${ }^{2}$ Many research participants discussed this in ways that align with but don't explicitly use Sevilla Guzmán's 'ecological/productive, socioeconomic, and sociocultural and political' triad (2015). Since that more specific language was not used by research participants, we utilize broader environmental, economic, and social categories throughout this paper.
} 
complementarities existing in nature, and relies less on external inputs (De Schutter 2014). Agroecology in Argentina also draws particularly from the knowledge of Indigenous farmers as an alternative to chemical inputs (Perez et al. 2018). It is important to note, however, that the practice of agroecology is fluid and producers do not always starkly distinguish their practice from other technical approaches. Instead, agroecology practitioners articulate flexible values and principles that adapt to local contexts. Tornaghi (2017) and Tornaghi and Dehaene (2019) point to the expansion of a loosely-defined and under-theorized urban agroecology that seeks to address power structures and disrupt capitalist urbanism-food regimes through recognizing the co-existence of urban functions, agroecosystems, and human and nonhuman biotopes.

We contribute to urban agroecology literature by drawing from urban political ecology (UPE) theories of socionatures, urban metabolisms, and assemblages in order to better understand the socio-political goals, bodies, and power relationships constituted through urban agroecology initiatives. UPE scholars have considered the complex socionatural networks that maintain urban life (Heynen et al. 2006). Cities are (re)produced by constellations of uneven power relations that constitute an urban metabolism circulating matter, value and representations (Heynen 2014; Loftus 2019; Smith 2006; Swyngedouw 1996). Investigating such metabolic processes necessitates revealing and contending with the hybridity of socio-natures in urban food systems, including gardens (Castree 2001; Classens 2015; Swyngedouw and Heynen 2003). UPE scholars have also attended to the separation of society and nature produced by commercial agriculture and urbanization (Bellwood-Howard and Nchanji 2017). In the Rosario context, a UPE lens brings to light the power relations embedded in institutionalized agroecology and the socio-political construction of environmental spaces (e.g., agroecological territories), bodies (e.g., agroecological producers), and materialities (e.g., agroecological goods) which emerge from political ecological struggles, especially the production of territories and subjectivities.

We draw on the concept of assemblages as an analytic tool for interrogating how a specific set of actors (growers, urban and peri-urban land, produce, markets) and relations are constituted as valuable socio-natures in a broader context of land pressure and economic marginalization. Assemblages have been discussed as constellations of selected, organized, and stratified actors that code acceptable uses of spaces and places (Anderson and McFarlane 2011; Deleuze and Guattari 1987; Hammelman and SaenzMontoya 2020; among others). Constantly made and remade by changing information, lived experience, and contestations over resource use, assemblages are more than a sum of their parts. Some have theorized assemblages as two dimensional, with materiality (bodies, spaces, objects) on one axis and expression (meaning, narratives, discourse) on another axis (Tardiveau and Mallo 2014). DeLanda (2006) points to the importance of territorialization-understood as the struggles for spatial control through which territories are made and/ or claimed-which can operate as a more or less permanent articulation of place through which assemblages arise and maintain identity. Carolan (2015) argues that Deleuze looked to affect as a force for belying, disrupting, and transforming subjects within assemblages. Our research complicates this relationship between territorialization and affect within agroecological assemblages by highlighting bodies as a space of tension between materiality and expression. In reading the PAU and the Greenbelt Project as agroecological assemblages, we emphasize the interactions between territory, affective bodies, material, and discourse in producing agroecological socio-natures that circulate through the urban metabolism.

Examining food projects through the coming together of affective and effective assemblages allows us to identify the ways in which social change, value, and politics are cocreated and enacted. Rather than focusing on these urban and peri-urban agroecology programs as separate institutional actors responsible for policies and programs that enable access to territory, seeds, and water; foster systems of exchange via local markets; and support the exchange of traditional agricultural knowledge, we argue that their persistence relies on the dynamic entanglements of bodies and nature, selected and organized through program imperatives, but relationally constituted through land, labor, and the agroecological materialities of fruits and vegetables. Assemblage actors' framing of bodies, place, nature, and material relationships through the lens of agroecology produces subjectivities and roles for growers, consumers, and institutions as stewards of the land, economy, and social justice.

Utilizing assemblages as a lens aligns with other frames that recognize the complex, multi-dimensional nature of agroecology through multilevel domains of transition (Anderson et al. 2019, 2020) and territories in dispute (Giraldo and Rosset 2018). However, we find assemblage thinking is a particularly helpful frame for attending to the inter-relations of territory, material, bodies, and discourses that become together, producing more than their sum as aggregated elements. We focus on the tripartite nature of agroecology as interweaving environmental, economic and social concerns, and examine how this co-constitutive set of relations and actors become together differently in two mutually informing institutionalized agroecological interventions. Examining differences between the two assemblages in terms of scale (urban or peri-urban), staff and growers, and emphasized modes of productivity (marginal land or marginalized residents) highlights the way these complex networks pursue related yet different objectives. Importantly, these assemblages are ever-changing, enabling the agency 
of specific actors in different spaces and times. In attending to differences between these assemblages, we also respond to calls for better thinking through relations of power and issues of subjectivity that produce and are produced through assemblages (see Kinkaid 2020).

The agroecology programs in Rosario are managed and supported by the municipal government (as described below). These institutional programs face critiques of cooptation by UA producers operating outside the government programs, echoing broader critiques of the institutionalization of agroecology as co-optation (Giraldo and Rosset 2018). However, examining these programs as agroecological assemblages belies the two-dimensional tension between a radical agroecology and its recuperation and neutralization through institutionalization. Instead, through assembling territory, bodies, discourse, and material, more complicated notions of appropriate territorial uses and subjectivities are fomented. Rosario's PAU and Greenbelt programs offer participants a great deal of autonomy, emphasize the importance of Indigenous and peasant knowledge, and seek innovative solutions to transform the local food economy. Yet, PAU proscribes UA to marginal lands, and both programs largely value agroecological bodies as market contributors. The UA advocates in this research understood political support as central to program sustainability, recognizing the need for institutional resources and policies. Given the complexity of these relationships, we are careful not to reject institutional agroecology as inherently co-opted. Instead, we consider how institutional approaches can further goals that counter mainstream capitalist and industrial food production, while at the same time remaining constrained in their efforts to produce systemic transformation.

\section{Urban and peri-urban growing in Rosario}

The data presented in this paper derive from in-depth, semistructured interviews ranging from $20 \mathrm{~min}$ to $2 \mathrm{~h}$; community meetings; and informal conversations and observations (at markets, municipality-sponsored and independent gardens, and municipality-organized tours and events) completed in July 2018 and May-June 2019. Prior to completing fieldwork, the authors analyzed government reports and public descriptions of the programs (e.g., FAO 2014) as background information. Ethnographic research (participant observation in municipality-sponsored and independent UA spaces and unstructured ethnographic interviews with participants), carried out by one co-author during June-November 2013 (Shoffner), supplemented this data, provided context and allowed the authors to connect with key informants. In total, more than 30 stakeholders, representing government, grassroots organizations and growers shared their experience and knowledge with the authors.
Interview themes were derived from larger multi-sited UA research in four Western Hemisphere countries. Stakeholders discussed their experiences with food production in urban or peri-urban spaces, their motivations for becoming involved, the value they perceive urban and/or peri-urban agriculture provides for food systems, and barriers to implementation and practice. Qualitative data from interviews and field notes were coded in NVivo 12 software using a combined inductive/deductive approach. The code architecture included pre-established codes drawn from the lead author's broader multi-sited research program, augmented with open and axial coding of emergent themes from data produced in Rosario, which organized the analysis presented here.

Rosario is a port city of approximately 1.2 million people, making it the third largest city in Argentina (INDEC 2010). It has a significant industrial corridor where ongoing urbanization for industry, including that associated with the port complex and agroexport industries, vie for real estate space with peri-urban and urban farming production. As spaces become commodities for competition, tensions arise in efforts to support farmers and agroecological systems. Rosario is unique in Argentina for the continuity of socialist municipal governments over the last three decades, which have tended to continue policy approaches of previous governments (including an emphasis on transparency, accountability, and participation) (Hardoy and Ruete 2013). The municipal government has a long history of urban planning with a focus on social policies.

Rosario is centrally located in the pampa húmeda, the principal agricultural region of Argentina, with an emphasis on the industrial production of soy, wheat, and corn (INDEC 2019), much of it genetically modified. Located along the primary navigable river of Argentina, the Paraná, and at the intersection of two railroad lines and several major highways, Rosario is a key hub of the agroexport economy. The ports of Greater Rosario account for over $70 \%$ of grains, subproducts and oils shipped from the country (FAO 2015; Gorenstein 2005). Since the 1990s, Argentina has experienced agrarian transformation driven by intensive farming of genetically modified soybeans as a commodity crop exported worldwide (Leguizamón 2020), associated with broader processes of neoextractivism and reprimarization throughout Latin America (for a critical discussion, see Svampa 2012). The growth of Argentina's large-scale soy production sectors was made possible, in part, through neoliberal restructuring and demand for such non-traditional commodities from China and India (Leguizamón 2020). While this transformation has been celebrated as an economic and modernization success by some, others point to the great social and ecological harm it has produced. In particular, the intensification and expansion of soybean production has accelerated deforestation, land concentration (through both ownership and management) and dispossession, rural poverty, and the 
disappearance of small farms, with an increase in food insecurity and loss of regional economies and food sovereignty (Pengue 2005; Svampa and Viale 2014). These processes drive regional migration to Rosario with migrants frequently settling on the outskirts of the city in informal settlements. Further, as soybean production replaces traditional crops, land is increasingly concentrated, and economic growth slows; food insecurity in rural areas, and among rural-urban migrants, has increased (Leguizamón 2020).

According to research participants, urban gardening grew in informal settlements as a way to supplement food intake during the mid-to-late 1980s-1990s. In 1991, the National Institute of Agricultural Technology (INTA), in conjunction with the National Ministry of Agriculture and Fishing, began the program ProHuerta as part of the National Food Security Plan (CIPPEC 2012). ProHuerta, as a national program, supports small-scale, subsistence production of fresh foods in low-income urban and peri-urban areas across Argentina. It provides resources to spontaneous and independent gardening projects (INTA 2011). ProHuerta became a part of the backbone of UA in Rosario, promoting agroecological farming and working parallel to non-profit organizations that also provided seeds (Bracalenti et al. 2012). Throughout the 1990s, these projects, as well as UA more generally, continued to expand. In 2001, Argentina suffered the most important economic crisis in its recent history, leaving many, particularly in Rosario, without jobs and hungry. Approximately one third of the workforce was unemployed and $60 \%$ of the population had an income below the poverty line (FAO 2015). As a result of the crisis, many turned to UA, often in empty lots precariously occupied or ceded for this use (Bracalenti et al. 2012).

As part of widespread efforts to support economic activity and fight hunger, the Rosario Municipal Government started the Urban Agriculture Program (PAU), which today resides within the Secretariat of Social Economy. We understand the constellation of actors operating in and through PAU as an assemblage that codes marginalized bodies, agroecological practices and materials, and under-utilized urban territories as valuable socio-natures. PAU advocates perceived many of its growers as marginalized by socio-economic systems that devalue under-resourced migrants and residents of informal settlements. The PAU assemblage operates at the municipal scale and emphasizes growers' environmental and economic contributions to the urban metabolism. In 2002, in partnership with ProHuerta and a local NGO, the Rosario government planned to support 20 gardening groups with tools and seeds. Within two years, funds for equipment, inputs, and training increased to support 800 community gardens, producing food for nearly 40,000 people (Guénette 2010). According to Guénette, funding from multiple sources, such as prize money, collaboration with international institutions and cross-funding from other municipal and provincial programs supported this expansion. PAU also supported home and school gardens, and among the three venues produced 1400 tons of food (Mazzuca et al. 2009).

In this process, the spontaneous garden initiatives produced during the crisis were consolidated and institutionalized in larger, more permanent spaces based on a participatory mapping of land use for UA in 2003 (Bracalenti et al. 2012). Given the land use pressures within the city, PAU incorporated gardeners into institutional garden spaces on land that could not be developed through legal agreements which ceded use of the land, creating today's "garden parks" (parque huertas). Through the garden parks, organized as allotments, PAU sought to establish more formal spaces of urban cultivation that rely on agroecology principles and provide greater economic opportunities for producers. Today, UA remains a vibrant activity, with nearly 250 families participating in six garden parks stretching across 30 hectares of public land (FAO 2014). Many of the participants are low-income residents who live in informal settlements near the gardens. PAU supports producers by providing a plot of land, needed inputs, technical support from agronomists, and access to farmers' markets. While PAU is the largest UA actor in Rosario, many other grassroots or non-profit community gardening efforts operate throughout the city. These independent gardens often receive some level of support from national or provincial programs to support commercialization of products, the sustainability of UA as a source of income, or the provision of seeds or space.

In 2011, members of the Rosario Municipal Government started the separate, but related, Greenbelt Project in order to strengthen agroecological farming in peri-urban areas (Terrile 2011). We understand the Greenbelt assemblage as constituted through peri-urban stakeholders (growers and advocates), territory, markets, and institutional policies. The Greenbelt assemblage is distinct from the PAU assemblage in that it operates at a peri-urban scale, emphasizes the productivity of agroecological territory, and discursively represents its producers as farmers marginalized by the industrial food system. The Greenbelt Project is located in the Secretariat of Economic Development, Innovation, and Employment and coordinates with the municipal secretariats of Environment and Public Space, Public Health, and Human Development. It also receives technical and financial support from the Province of Santa Fe's Ministry of Production (Battiston et al. 2017). According to the Municipality of Rosario, the Greenbelt Project aims to address concerns surrounding environmental contamination, food safety and quality, and food sovereignty ${ }^{3}$ by providing training in good agricultural

\footnotetext{
${ }^{3}$ In interviews, the mention of "food sovereignty" was generally described as an aspirational ideal, often during discussions of the evolution of programs like Pro-Huerta and PAU from crises of food security. However, by explicitly contrasting these programs to the exclusions produced through the agro-industrial-export model expe-
} 
practices and incentivizing the transition to agroecological practices. The municipality advertises seven markets in the city in which produce from the Greenbelt is sold. The Greenbelt Project began by converting 40 hectares of land to agroecological production in partnership with individual producers. By October 2019, it included nine producers that together cultivated 73 hectares of land using agroecological methods and 142 hectares of land in transition to agroecological methods (Latucca 2019). Greenbelt staff provide technical support, assist in acquiring seeds and other inputs, and host farmers' markets.

Importantly, actors in both the PAU and Greenbelt assemblages emphasize agroecology as the integration of ecologically-sound practices, economic viability with more direct connections between consumers and producers, and social justice and inclusivity. One researcher involved in both assemblages noted:

PAU, and now the Greenbelt Project, were always conducted with a real agroecological focus. They always had the social piece, the productive economic piece and the environmental piece in mind. Always. So there was always research, training, production, social assistance-all the steps were always taken.

This means that in addition to producing agricultural goods through agroecological methods, actors in these assemblages emphasize the need to support the social integration of producers and to provide an economic outlet for selling their goods.

Yet, these two programs and associated growers strategically and discursively territorialize agroecological assemblages through an emphasis on different aspects of the environmental-social-economic triad. Institutional stakeholders and producers in both programs highlighted environmental components, describing their work as contesting the negative effects of industrial agriculture and creating healthier (clean) bodies and environments (see more below). However, as a social integration program, PAU focuses on UA as a form of labor which mediates the social consequences of industrial agriculture, including displacement from agriculture in the interior of Argentina and the urban exclusion and poverty of migrants. It further emphasizes that UA is valuable work that residents of the periphery with deep agricultural knowledge provide, and thus makes visible these urban metabolism contributions to privileged city residents. While also interested

\section{Footnote 3 (continued)}

rienced acutely in Rosario through the GM soy boom, interviewees were also making a political claim about the role of the local government in supporting local control of food production, consumption, and decision-making. This included efforts to establish a local participatory certification system, which was also associated with the term "food sovereignty". in social dimensions, the Greenbelt emphasizes an economically productive peri-urban agricultural corridor. It makes claims for the economic viability of agriculture in urban/ peri-urban land and the productivity of peri-urban agroecology for urban food markets. Central to this valorization of peri-urban agroecology are the intergenerational and placebased connections to land and the ecological expertise of farmers. These agroecological assemblages are not entirely distinct, as they share geography, institutions, history, and staff, and thus, participate in forming each other. Yet we argue that their differences are important, as they produce related, yet different, socio-natures.

\section{Entangled socio-natures in agroecological assemblages}

Through its urban and peri-urban agroecology programs, the Rosario government constructs particular environmental spaces as agroecological landscapes that protect land from industry and urbanization while also making visible the productive capacities of agricultural producers economically and socially marginalized by poverty and the industrial food system. In the process, agroecological assemblages that exceed these municipal programs are constituted through institutional actors and strategies (seeking to preserve land for agricultural uses), discursive renderings of socio-natures (as valuable biodiverse territories and productive bodies), and the marketing of agroecological materialities (through public markets). This section discusses the strategies and discourses deployed within these assemblages operating at different scales, the socio-natures produced, and the power dynamics navigated.

\section{Institutional actions and territorial strategies to preserve agricultural lands}

Growers and staff from both the PAU and Greenbelt emphasized the need to protect peri-urban land from heavy industry, urban land from encroachments by informal settlements, and both from the impacts of industrial agriculture. They stressed that when rural land (which is sold in hectares) is converted to urban uses (and thus sold in square meters), the value of land can quintuple. Peri-urban land on the edges of the city is therefore increasingly transitioning to higher-value urban and heavy industry uses. These activities can lead to greater soil degradation, pollution, and flooding given that, according to agroecology advocates, industrial uses simply produce a "carpet of cement." Simultaneously, Rosario is located in the heart of industrial soybean production, which relies on chemical inputs and fumigations to produce high yields of monocultured commodities. Several peri-urban stakeholders 
expressed concern that such industrial production not only degrades the environment and threatens health, but also produces a disconnect between people and agricultural systems, evidenced by the disappearance of small, family farmers who held deep knowledge of the countryside.

Actors within the Greenbelt assemblage respond to these pressures by providing an alternative of agroecological production that emphasizes environmental, social, and economic values. In doing so, project stakeholders called attention to the productivity of the pampa húmeda and the threat of industrial production. One agronomist stated that large companies "create a disaster with soil degradation and pollution. We have a hegemonic productive model that goes against what we propose, which is to improve the quality of life through healthy eating." Another agronomist with deep agricultural knowledge from experiences in the interior of Argentina elaborated on these concerns:

The pampa húmeda is the most fertile earth in Argentina. And curiously, it's in the hands of soy farmers, large wheat producers, and other large productions that are exported by businesses in Buenos Aires, to the detriment of the entire country's population.

In response, the Greenbelt is strategically and discursively constructed as an alternative that rejects monocultures, genetically modified seeds and the power of seed companies, and the unequal distribution of food resources. In doing so, peri-urban territory is framed as a productive agroecological alternative that contests the industrial food system, protects the environment, and contributes to the urban metabolism.

Actors within the PAU assemblage strategically use community gardens to protect land from encroachments by informal settlements, particularly in spaces deemed unlivable due to proximity to roads, train tracks, and streams, while emphasizing their role in recuperating and preserving urban lands and creating green spaces. Especially following the 2001 economic crisis, individuals and collectives occupied land to establish gardens. But as the economy improved and construction continued, people lost that land and such encroachments were increasingly seen as an illegitimate land use. UA projects more broadly often struggle to maintain land tenure, especially when UA is perceived as a temporary land use to meet socio-economic needs during crises such as that experienced in Argentina (Bracalenti et al. 2012).

However, as a municipal project focusing on the urban scale, PAU described being bound by (and thus reproducing) logics of acceptable land use. PAU utilized land surveys to identify ideal garden sites as those that either cannot or should not be urbanized (according to municipal priorities) and do not compete with other uses. One research participant involved in early planning projects described these priorities:
So here in Rosario, there's land; when we did the land study, we realized that it was very important that urban agriculture doesn't compete with other urban uses. So, that agriculture is located in land that can't be urbanized. This was a very important first conclusion. On the other hand, it also served to preserve, for example, lands that flood, where if a marginal population settles, they are at high risk. So, there was also a plus to urban agriculture that allowed us to resolve serious problems like the occupation by housing in places that are dangerous for people to settle.

Being constrained by these logics means that most PAU gardens are located in marginal lands (some of which are subject to flooding). Similar to many grassroots movements, this institutional UA project remains constrained by capitalist urbanism logics that emphasize more profitable land uses.

Actors in both assemblages seek to overcome food system and urbanism constraints through constructing urban and peri-urban territories as agroecological natures. Through the organization of socio-natural relations and selective inclusions and exclusions in the territorialization of agroecological assemblages, these activities code agroecological territories as an alternative to heavy industry, urbanization, and conventional agriculture, and the social and environmental challenges presented by those processes. In doing so, they frame agroecology and agroecological producers as environmental stewards.

\section{Discursive renderings of (bio)diverse natures and bodies}

Discourses of biodiversity, changing relationships with the land, and social justice, which construct marginalized nature and bodies as critical to the urban metabolism, are constitutive elements of Rosario's agroecological assemblages. Agricultural producers and advocates discussed the importance of biodiverse landscapes that are created through agroecological growing. Greenbelt farmers reported that in learning and implementing agroecological practices, their understanding of and attitude toward the environment shifted. One peri-urban farmer said that he stopped referring to weeds as pests and instead began to view them as "spontaneous biodiversity". Another explained a change in his understanding of weeds and insects. In his agroecological practice, he sees weeds' role as accompanying the plants and distracting insects, all of which eventually improves the structural fertility of his land and reduces plants vulnerability. In this way, and as expressed by many others, he reported that agroecology is distinct from organic agriculture: it is not just about using different agricultural inputs, but instead about developing a different relationship with the land. Tornaghi and Dehaene (2019) similarly reflected that 
the Rosario programs promote agroecology as a way of life "deeply rooted in the understanding of trans-species ecological interdependencies" (p. 11). This co-constitution of interdependent socio-natures aligns with agroecology principles in ways that are not often expected of institutional actors.

Entangled with such agricultural biodiversity are the producing bodies that tend agroecological spaces and consume agricultural goods. In highlighting the role of producers' and consumers' bodies, we consider how affective experiences with nature, as well as embodied ways of understanding and evaluating nature, further shape perceptions, motivations, and decision-making. Within these assemblages, the positive impact of agroecological approaches on the bodies of producers and consumers was emphasized. This included highlighting the negative health impacts that producers have or could experience from regular exposure to chemical inputs in industrial agriculture. One peri-urban farmer recalled using agrochemicals from age eight and stated "it [fumigation] was systemic poison. Your back got wet and you were poisoned." Another farmer explained that "we're living in a contaminated environment and our bodies are constantly being contaminated. It's important to eat these [agroecologically produced] foods to be able to clean and purify ourselves." As a result of these bodily experiences, farmers were conscientious about how they produced their crops and what they decided to eat. Several farmers and gardeners reported that their motivations for being involved in the agroecology programs stemmed from a desire to protect not only the health of their land in order to improve its long-term productivity and biodiversity, but also their and consumers' health from the effects of agro-toxins, thus positively impacting the urban metabolism.

Through narratives regarding the bodily impacts of agrotoxins on both producers and consumers, these agroecological assemblages construct bodies that are 'healthy' and 'clean' as a result of engagements with agroecological production and in contrast to bodies produced through conventional agriculture that are 'poisoned'. They also emphasize their urban and peri-urban contributions of building diverse urban and peri-urban natures. By highlighting the positive effects of agroecological production for the environment and bodies, the discursive aspects of these assemblages point to the co-constitution of nature and society in the formation of urban and peri-urban agricultural spaces. Constructing value through the contributions of biodiverse lands and bodies is perceived as critical for sustaining support for the programs and moving agroecological production from the margins of Rosario's food system.

\section{Marketing agroecological goods and services}

Through an emphasis on the material value of agroecological goods and services, actors in the PAU and Greenbelt assemblages demonstrate their economic impact on Rosario's urban metabolism, thus making these agroecological materialities central to the production of urban socio-natures. Greenbelt producers sell their goods at six farmers' markets on 6 days per week, in addition to a permanent stall in El Mercado del Patio. This permanent stall is part of a renovated market across from the bus terminal with other shops selling artisan and organic products, and restaurants that cater to travelers and Rosarinos who live and work in the wealthier city center. PAU gardeners sell their goods in 12 markets with different locations around the city on different days of the week. At least one large market on the weekend typically hosts both PAU and Greenbelt producers in different stands but otherwise the markets do not overlap.

The economic emphasis for PAU originates, in part, from its evolution out of the 2001 economic crisis and the need to provide economic opportunities for participants. In contrast to pre-crisis programs that emphasized subsistence production, PAU focuses on UA as a legitimate space of labor and economic incorporation of those often marginalized in the formal labor market. This was explained by one of the municipality's agronomists:

There were no ferias before. And so the idea was that people who were unemployed could produce vegetables and sell them in the ferias. For the first time, the people of Rosario could have agroecological vegetables because, at this time, there were none. And that's how it began.

This emphasis on individuals producing for profit, rather than subsistence, was stressed as critical to PAU's success. One community garden leader explained that she joined PAU because of the economic difficulties she faced at that time. "There was no work. You couldn't get a job... But since I knew how to cultivate the land, cut wood, and those things, it seemed to me that working the land resulted in getting food." For some families, the profit from the markets is a supplement to income, while for others it represents their family's entire income, often replacing informal activities.

A municipal agroecologist involved in the creation of the PAU markets also emphasized their importance in enabling the productivity of marginalized producers to be physically visible in the city in new ways. The markets were described by a UA advocate as "spaces of exchange" where "a link between people is formed and there is a cultural dialogue." As "zones of encounter" (Farías 2018; Lawson and Elwood 2014; Valentine 2008) created through the "solidarity economy" fomented by the municipality (later renamed the "social economy"), markets not only provide important economic opportunities for agroecological producers, but also enable crossing boundaries between low-income agricultural producers and wealthier consumers in the central city. 
By placing producers in front of consumers, markets create an opportunity for sharing knowledge, skills and experience, rendering valuable the labor of producers marginalized by the industrial food system and urban poverty. Producers are made physically visible in central city spaces they otherwise would not frequent (or feel welcome), supporting an exchange of knowledge that allows consumers to acquire food from 'somewhere.' Government officials, researchers and producers in both assemblages also sought to inform the public about the benefits of eating fresh food that does not contain agro-toxins. One gardener (who sold seedlings) identified his motivations for being at a market as not just to sell but also to share his knowledge. Yet it is not clear what the effects of these agroecological sites of cross-class encounter may be for changing public perceptions about marginalized producers.

While PAU emphasizes the economic and environmental productivity of low-income growers, the Greenbelt assemblage focuses on the economic productivity of agroecological lands and technological approaches in order to prevent the advance of industrial farming. Greenbelt advocates reported that demonstrating the economic value of agroecology was critical to a successful agroecological transition. Accordingly, Greenbelt stakeholders emphasized the value of agroecological methods in order to garner a fair price for their goods. In markets, producers have the opportunity to explain their farming practices and share their knowledge with consumers. One peri-urban farmer described this experience:

We talk about it with people and they understand, we explain why, because it takes a little bit more work to grow agroecologically. Conventional growing you can say is industrialized, our work is more artisanal... Because it's more of an artisanal job and we put in a little bit more work, which makes it so we talk more with the people at the feria about prices, but they understand and it's not like we're trying to speculate prices for a larger profit, because the idea is to sell at a fair price. A fair price doesn't mean that something's cheap, it's not that it should be free, cheap, rather it should be fair enough so you can produce it, you can buy it and there's no slave labor behind it.

The emphasis on productivity - of growers and agroecological lands-is important for providing legitimacy to UA. In order to continue to garner institutional support, the socio-natures organized through agroecological assemblages must be perceived as contributing not only to the capitalist economy, but to social and ecological goals (as also represented by the agroecology triad discussed above). One UA advocate explained these contributions:
Urban agriculture has many benefits and apart from the fact that people from the city have access to vegetables free of agro-chemicals, they can also relate with nature because today life's rhythm is so fast and keeps getting faster, but places like this [a teaching garden], one is in a place, at least a small space, in another world. It helps so one feels better.

These discourses of productive socio-natures embody urban political ecology subjectivities by crossing societynature divides in the city (Tornaghi and Dehaene 2019).

The ability to make significant gains in recognizing UA as part of the urban metabolism is constrained by national and international neoextractive developmentalist narratives and policies that prioritize industrial agriculture, politicaleconomic forces that value different land uses, and the disconnect between people and food systems produced by modern urbanization. Nonetheless, the markets as "zones of encounter" are an emergent space produced through the agroecological assemblages we examine, brought into being with productivity frameworks that emphasize the value of both the material goods produced and the marginalized bodies that produce these goods.

\section{Institutionalizing agroecological socio-natures}

Whether in claiming land from conventional agriculture, industry or urbanization, deploying discourses of biodiversity and cleanliness, or emphasizing the material productivity of agroecological lands and producers, the entanglement of socio-natural elements is critical to stabilizing the contingent relations that produce agroecological assemblages in Rosario. Understanding these elements of Rosario's agroecology programs as assemblages makes clear that together they are more than the sum of their parts. Instead, this relational organization of land, bodies, and material, producesrather than being produced by - the institutional success and relative longevity of these urban and peri-urban agroecological programs. This complex institutional formation is embedded in power relationships that, on the one hand, can constrain efforts toward agricultural and social transitions, but, on the other hand, provides prefigurative power to begin building alternative food futures.

While many parts of these two agroecological assemblages overlap, there are important differences between them. Both are formed through territorial strategies, discourses of environmental and bodily health, and the material production of natures and bodies. However, at one level, PAU and Greenbelt advocates and participants did not mix. Government staff supporting each program were generally situated in different secretariats, and municipal markets 
included either urban or peri-urban growers, but not both. Several people interviewed for this research reported a perception that PAU gardeners and Greenbelt farmers were different kinds of people. PAU gardeners were often discussed as more recent migrants, first generation growers, working at a smaller scale, and engaging in UA because of economic crisis or for a connection to practices in their region of origin. Greenbelt farmers were perceived as growers who have been farming for generations, have been in the area longer, are owners or tenants of larger-scale pieces of land, and are more motivated by business goals.

The priorities of each program are also divergent in ways that make it challenging to develop a regional food system operating across urban and peri-urban scales. It became clear that despite alignment in broad goals, the specific emphases and institutional versions of agroecology differed. One key difference is the emphasis on the productivity of agroecological systems in the Greenbelt assemblage compared to the emphasis on the productivity of growers on the city's periphery in the PAU assemblage. This was highlighted by one agroecologist central to both programs as an issue of scale. They explained that the agroecological production of PAU gardeners allowed families to access a modest income through their labor, enabled through the stability of the municipal market infrastructure. However, this was limited in its ability to dramatically shift the urban metabolism with regards to local agroecological food production at the city scale-something they implied was achievable through the larger-scale agroecological transition of peri-urban land in the Greenbelt assemblage.

The division between the programs may serve strategic goals, however, as it allows the programs to operate in different municipal secretariats and garner greater institutional support. Many research participants pointed out that being positioned within the municipal government was critical to the longevity and success of the programs. Given that growers in the PAU and Greenbelt assemblages already live at the margins with limited resources, having government support has been essential for enabling their participation. One agronomist noted that the government's economic support of these programs is important but so is the legitimacy that is provided by having such backing. At the same time, the international attention that these programs receive raises the profile of the city itself and these programs within the city (FAO 2014; among others). While the current scale of the assemblages is small, actors within them seek to chip away at capitalist and industrial food systems that dispossess people of food, land, and relationships. As such, we find that they are pursuing a prefigurative praxis that, as described by Tornaghi and Dehaene (2019), honors the use value of soils and labor and makes visible urban ecological rifts. Some UA advocates in Rosario recognize that the current configuration of these agroecological assemblages are only a "patch" in this effort, but they also argued for the agency of growers constructing agroecological alternatives and resisting cooptation. For these advocates, municipal relationships have been critical for sustaining resources for this work.

In this case study, we seek to complicate expectations of institutional agroecology. Giraldo and Rosset (2018) express concern about institutional agroecology that is technocentric, converts communal property rights into private property, and precludes life outside the market. Instead, a 'people's agroecology' is deeply political, as it champions distributive justice, rethinking food systems, and building peasant autonomy. In Rosario's agroecological assemblages, this distinction is less clear. Actors in the PAU and Greenbelt assemblages push for rethinking food systems as complex socio-natures instead of technical systems, with roots in both grassroots social movements and a socialist municipal government. The institutions make land and material goods available (providing seeds, supporting efforts to save seeds, forming markets), bring attention to social justice concerns in the food system, environment, and urban policy, and promote agroecology as a way of life.

Yet, the government also utilizes these programs to protect urban land from encroachments of informal housing and squatting on land deemed unfit for residence, which city planners and architects perceive as a benefit of incorporating UA into territorial planning (Bracalenti et al. 2012). Perhaps more importantly, and as discussed above, the institutional programs also struggle to disrupt conventional urban land policy such that they remain relegated to marginal spaces. As the land that some growers are provided is vulnerable to flooding, they are at risk for losing their produce, which creates difficulty for achieving PAU's economic goals. Actors within the Greenbelt assemblage seek to demonstrate the value of agroecology on peri-urban land and to register growers as market producers so that they have more ownership of their profits, but have otherwise been unable to support redistribution of land to agroecological farmers and a lack of secure land tenure remains a salient challenge. Further, the land and resources provided by the government can raise questions about grower autonomy. Gardeners reported lacking sufficient seeds, land, and appropriate machinery and tools (although this remains true without government involvement). When the national government is controlled by more neoliberal parties (such as Macri's PRO), gardeners report receiving less seeds than before and expressed concern about the continually rising cost of seeds. ${ }^{4}$ Others

\footnotetext{
${ }^{4}$ While this constraint is especially acute for growers directly involved in PAU and the Greenbelt Project, the vast majority of grassroots UA projects in Rosario are also supported in some way by government programs. For instance, one garden established by an asamblea during the 2001 crisis that is quite critical of PAU receives provincial government funding to pay students and young people to participate in garden programs, thus claiming institutional resources for agroecological ends.
} 
expressed concern about losing resources and/or program support with the potential change of government officials after each election. Thus, institutional embeddedness constrains the ability to scale up agroecology and to pursue more radical transitions.

Such tensions were frequently evident in this research and bring to light the complexity of institutional agroecology. Yet we are not convinced that these constraints mean institutional programs should be dismissed as cooptation. In the Argentine context, where claims to institutional resources have been simultaneous with social movement struggles for autonomy,${ }^{5}$ the agency of growers in shaping these assemblages should not be overlooked. At the same time, the relationship between autonomy and cooptation is not a linear continuum, such that it is possible for initiatives to be functional to capitalism and state legitimacy, while also being the product of collective struggle from within and beyond the state. As institutional actors and growers who participated in this research emphasized, social equity and inclusion are fundamental to agroecological transitions; thus, there is a need for transparent and participatory decision-making and reflective praxis in order to guard against cooptation and continue to foster self-determination.

\section{Prefiguring urban and peri-urban agriculture futures}

In this paper, we discussed long-standing, institutional, urban and peri-urban agroecology initiatives in Rosario, Argentina, as co-constitutive assemblages forming socionatures critical for the urban metabolism. Examining multiple and overlapping agroecological transitions envisioned by PAU and the Greenbelt Project through the lens of agroecological assemblages allows us to consider how agriculturally productive territories, laboring bodies, and agroecological products become together in different arrangements to meet the integrated goals of environmental, social and economic sustainability theorized by agroecologists and stressed by practitioners within this research. As such, agroecological assemblages belie the possibility of agroecological transitions as a purely technical fix. Furthermore, through utilizing an assemblage approach, we can consider how the environmental, social and economic triad of agroecology comes together through variable processes of ordering and in/exclusion. For instance, in the Greenbelt assemblage, an emphasis on the agricultural productivity of peri-urban areas produces understandings of agroecological goods as artisan

5 For instance, the piqueteros or unemployed worker's movement (movimiento de trabajadores desocupados) (Chatterton 2005; Dinerstein 2003) are key examples in this long history of struggle. products that demand fair prices. At the same time, the emphasis in the PAU assemblage on marginalized producers constructs value through notions of social inclusion. While these emphases are related, in practice they create differing notions of the value of agroecology and the subjectivities of agroecological growers, consumers, and institutions.

We attend to the collective enactment of social change, value, and politics in institutional UA through relational entanglements that seek to preserve land for agricultural uses, value biodiverse territories and laboring bodies, and market agroecological materials, while also facing challenges in accessing resources, generating widespread interest, and disrupting existing land policies. These agroecological assemblages move beyond ideas of urban and institutional agroecology as too small-scale or inherently co-opted, highlighting the multi-dimensional productivity of these programs. In Rosario, what might be read as the territorialization of municipal programs domesticating more radical irruptions of agroecology in urban space, are in fact continually reworked by the affect, desires and embodied labor of program participants. Thus, as assemblages, they engender novel emergences, like the markets as spaces of cross-class encounter centering the agroecological knowledge of producers.

In order to sustain their work, advocates and growers in the PAU and Greenbelt assemblages sought to demonstrate their contributions to the urban metabolism in increasing biodiversity, healthy territories and bodies, and productivity. In doing so, they pursue a prefigurative praxis that intervenes in the capitalist urbanism-food regime through demonstrating the critical value of co-constituted socio-natures for the urban metabolism. They emphasized agroecology as a way of life grounded in ecological interdependencies and farmerled ways of knowing. While the institutional relationship is complex, it offers an opportunity to pursue alternative imaginaries of urban food systems grounded in food sovereignty. One agroecologist employed by the municipality succinctly explained this objective: "Our goal is always that the most dispossessed, the weakest can have levels of freedom that do not depend on anyone."

Acknowledgements The authors would like to express their gratitude to all of the producers and advocates that shared their expertise and time with us during this research and that continue to pursue the creation of more ecologically and socially just food systems. Thank you also to Bryan Dale for his helpful comments on early versions of this paper and to the editor and three anonymous reviewers for their constructive comments. This work was supported, in part, by funds provided by the University of North Carolina at Charlotte. The authors maintain responsibility for any errors or omissions. 


\section{References}

Altieri, M.A., and C.I. Nicholls. 2018. Agroecology: A brief account of its origins and currents of thought in Latin America. Agroecology and Sustainable Food Systems 41 (3-4): 231-237.

Altieri, M., N. Companioni, K. Canizares, C. Murphy, P. Rosset, M. Bourque, and C. Nicholls. 1999. The greening of the "barrios": Urban agriculture for food security in Cuba. Agriculture and Human Values 16 (2): 131-140.

Anderson, B., and C. McFarlane. 2011. Assemblage and geography. Area 43 (2): 124-127.

Anderson, C., C. Maughan, and M. Pimbert. 2018. Transformative agroecology learning in Europe: Building consciousness, skills and collective capacity for food sovereignty. Agriculture and Human Values 36: 531-547.

Anderson, C.R., J. Bruil, M.J. Chappell, C. Kiss, and M.P. Pimbert. 2019. From transition to domains of transformation: Getting to sustainable and just food systems through agroecology. Sustainability 11 (19): 5272.

Anderson, C.R., J. Bruil, M.J. Chappell, C. Kiss, and M.P. Pimbert. 2020. Agroecology now!: Transformations towards more just and sustainable food systems. Cham: Springer.

Battiston, A., G. Porzio, N. Budai, N. Martínez, Y. Pérez Castella, R. Terrile, M. Costa, A. Mariatti, and N. Paz. 2017. Green Belt Project: Promoting agroecological food production in periurban Rosario. RUAF Urban Agriculture Magazine 33: 52-54.

Bellwood-Howard, I., and E.B. Nchanji. 2017. The marketing of vegetables in a northern Ghanaian city: Implications and trajectories. In Global urban agriculture, ed. A. Winkler-Prins, 79-92. Wallingford: CABI.

Bracalenti, L., S. Copello, E.M. Falbo, G. Godoy Garraza, E. González, L. Lagorio, M. Manzoni, S. Masondo, and R. Terrile. 2012. Agricultura familiar y acceso a la tierra urbana y periurbana: Marco normativo y estrategias jurídicas. Godoy Garraza G., and M. Manzoni (Eds.). Jujuy: Ediciones INTA.

Carolan, M. 2015. Adventurous food futures: Knowing about alternatives is not enough, we need to feel them. Agriculture and Human Values 33: 141-152.

Castree, N. 2001. Marxism, capitalism, and the production of nature. In Social nature: Theory, practice, and politics, ed. N. Castree and B. Braun. Malden und Oxford: Blackwell.

Chatterton, P. 2005. "Making autonomous geographies: Argentina's popular uprising and the 'Movimiento de Trabajadores Desocupados' (Unemployed Workers Movement). Geoforum 36: $545-561$

Classens, M. 2015. The nature of urban gardens: Toward a political ecology of urban agriculture. Agriculture and Human Values 32 (2): 229-239.

Dale, B. 2020. Alliances for agroecology: From climate change to food system change. Agroecology and Sustainable Food Systems. https://doi.org/10.1080/21683565.2019.1697787.

Centro Implementación de de Políticas Públicas para la Equidad y el Crecimiento [CIPPEC]. 2012. La implementación del Plan Nacional de Seguridad Alimentaria en ámbitos subnacionales. CABA: CIPPEC.

De Schutter, O. 2014. Agroecology and the right to food. Interview by Margriet Goris. Leisa India, 18-19. Retrieved from http://www.fao.org/agroecology/database/detail/en/c/443400/. Accessed 17 Jun 2020.

DeLanda, M. 2006. A new philosophy of society: Assemblage theory and social complexity. London: Continuum International Publishing Group.

Deleuze, G., and F. Guattari. 1987. A thousand plateaus. Minneapolis: University of Minnesota Press.
Dinerstein, A. 2003. Power or counter power? The dilemma of the Piquetero movement in Argentina post crisis. Capital and Class 81: $1-8$.

FAO. 2014. Growing greener cities in Latin America and the Caribbean: An FAO report on urban and peri-urban agriculture in the region. Rome: Food and Agriculture Organization.

FAO. 2015. Urban and peri-urban agriculture in Latin America and the Caribbean: Rosario. Retrieved from http://www.fao.org/ag/agp/ greenercities/en/GGCLAC/rosario.html. Accessed 17 Jun 2020.

Farías, M. 2018. Contesting exclusion: Solidarity spaces and changing political subjectivities in Buenos Aires. Geoforum. https://doi.org/ 10.1016/j.geoforum.2018.05.001.

Francis, C., G. Lieblein, S. Gliessman, T.A. Breland, N. Creamer, R. Harwood, L. Salomonsson, J. Helenius, D. Rickerl, R. Salvador, M. Wiedenhoeft, S. Simmons, P. Allen, M. Altieri, C. Flora, and R. Poincelot. 2003. Agroecology: The ecology of food systems. Journal of Sustainable Agriculture 22 (3): 99-118.

Giraldo, O.F., and P.M. Rosset. 2018. Agroecology as territory in dispute: Between institutionality and social movements. The Journal of Peasant Studies 45 (3): 545-564.

Gliessman, S. 2007. Agroecology: The ecology of sustainable food systems, 2nd ed. Boca Raton: CRC Press. https://doi.org/10.1201/ b17420.

Gliessman, S. 2020. Transforming food and agriculture systems with agroecology. Agriculture and Human Values 37: 547-548.

Gorenstein, S. 2005. Nueva institucionalidad y proyección local tras la privatización portuaria argentina: Los casos de Bahía Blanca y Rosario. EURE (Santiago) 31 (92): 105-122. https://doi.org/10. 4067/S0250-71612005009200006.

Guénette, L. 2010. Case study: Rosario, Argentina-A city hooked on urban farming. Ottawa: International Development Research Centre.

Hammelman, C., and A. Saenz-Montoya. 2020. Territorializing the urban-rural border in Medellín, Colombia: Socio-ecological assemblages and disruptions. Journal of Latin American Geography 19 (2): 36-59.

Hardoy, J., and R. Ruete. 2013. Incorporating climate change adaptation into planning for a liveable city in Rosario, Argentina. Environment and Urbanization 25 (2): 339-360.

Heynen N (2014) Urban political ecology I: The urban century. Progress in Human Geography, 38(4), 598-604.

Heynen, N., Kaika, M., and Swyngedouw, E., eds. 2006. In the nature of cities: Urban political ecology and the politics of urban metabolism (Vol. 3). Oxon: Taylor \& Francis.

Instituto Nacional de Tecnología Agropecuaria (INTA). 2011. Prohuerta. https://inta.gob.ar/documentos/prohuerta. Accessed 17 Jun 2020.

Isaac, M.E., S.R. Isakson, B. Dale, C.Z. Levkoe, S.K. Hargreaves, V.E. Mendez, H. Wittman, C. Hammelman, J.C. Langill, A.R. Martin, E. Nelson, M. Ekers, K.A. Borden, S. Gagliardi, S. Buchanan, S. Archibald, and A. Galvez Ciani. 2018. Agroecology in Canada: Towards an integration of agroecological practice, movement, and science. Sustainability 10: 3299-3316.

Kinkaid, E. 2020. Can assemblage think difference? A feminist critique of assemblage geographies. Progress in Human Geography 44 (3): 457-472.

Latucca, A. 2019. Promoting sustainable urban and periurban agriculture: An example of agroecology practices in Rosario. Video webinar for the Food and Agriculture Organization. https://fao. adobeconnect.com/_a1026619000/rpsuyw8gllh8/. Accessed 1 Oct 2019.

Lawson, V., and S. Elwood. 2014. Encountering poverty: Space, class, and poverty politics. Antipode 46 (1): 209-228.

Leguizamón, A. 2020. Seeds of power: Environmental injustice and genetically modified soybeans in Argentina. Durham: Duke University Press. 
Loftus, A. 2019. Political ecology III: Who are 'the people'? Progress in Human Geography 44 (5): 981-990.

Marchetti, L., V. Cattivelli, C. Cocozza, F. Salbitano, and M. Marchetti. 2020. Beyond sustainability in food systems: Perspectives from agroecology and social innovation. Sustainability 12: 7524.

Mazzuca, A., M. Ponce, and R. Terrile. 2009. La agricultura urbana en Rosario: Balance y perspectivas. Lima: IPES-Promoción del Desarrollo Sostenible.

Instituto Nacional de Estadística y Censos (INDEC) República Argentina. 2010. Censo Nacional de Población, Hogares y Viviendas 2010.

Instituto Nacional de Estadística y Censos (INDEC) República Argentina. 2019. Censo Nacional Agropecuario 2018: Resultados Preliminares-Agricultura.

Pengue, W. 2005. Producción agroexportadora e (in)seguridad alimentaria: El caso de la soja en Argentina. Revista Iberoamericana De Economía Ecológica 1: 46-55.

Perez, D., J. Seplovich, M. Gusman, and V. Vidal. 2018. Construcción de alternativas alimentarias en cuatro provincias de Argentina. Revista Colombiana de Sociología 41 (2): 21-40. https://doi.org/ 10.15446/rcs.v41n2.70260.

Rosol, M. 2010. Public participation in post-fordist urban green space governance: The case of community gardens in Berlin. International Journal of Urban and Regional Research 34 (3): 548-563.

Santandreu, A., A. Gómez Perrazoli, R. Terrile, and M. Ponce. 2009. Agricultura Urbana en Montevideo y Rosario: ¿Una respuesta a la crisis o un componente estable del paisaje urbano? Revista De Agricultura Urbana 22: 12-13.

Sevilla Guzmán, E. 2015. La participación en la construcción histórica latinoamericana de la agroecología y sus niveles de territorialidad. Política Y Sociedad 52 (2): 351-370. https://doi.org/10.5209/rev_ poso.2015.v52.n2.45205.

Smith, N. 2006. Foreword. In In the nature of cities: Urban political ecology and the politics of urban metabolism, ed. N. Heynen, M. Kaika, and E. Swyngedouw, xi-xv. Abingdon: Routledge.

Suzuki, E. 2012. A critical examination of urban agriculture: Evidence from Rosario, Argentina. McGill Institute for Health and Social Policy 4(1).

Svampa, M. 2012. Consenso de los commodities, giro ecoterritorial y pensamiento crítico en América Latina. Consejo Latinoamericano de Ciencias Sociales (CLACSO). Revista Del Observatorio Social De América Latina 32: 15-38.

Svampa, M., and E. Viale. 2014. Maldesarrollo: La Argentina del extractivismo y el despojo. Buenos Aires: Katz Editores.

Swyngedouw, E. 1996. The city as a hybrid: On nature, society and cyborg urbanization. Capitalism Nature Socialism 7 (2): 65-80.

Swyngedouw, E., and N. Heynen. 2003. Urban political ecology, justice and the politics of scale. Antipode 35 (5): 898-918. https://doi. org/10.1111/j.1467-8330.2003.00364.x.
Tardiveau, A., and D. Mallo. 2014. Unpacking and challenging habitus: An approach to temporary urbanism as a socially engaged practice. Journal of Urban Design 19 (4): 456-472.

Terrile, R. 2011. Propuesta de transición agroecológica para los cinturones de la provincia de Santa Fe. Una oportunidad para el desarrollo de sistemas agroalimentarios locales. Master's thesis, Universidad Internacional de Andalucía.

Toledo, V. 2011. La agroecología en Latinoamérica: Tres revoluciones, una misma transformación. Agroecología 6: 37-46.

Tornaghi, C. 2017. Urban agriculture in the food-disabling city: (Re) defining urban food justice, reimagining a politics of empowerment. Antipode 49 (3): 781-801.

Tornaghi, C., and M. Dehaene. 2019. The prefigurative power of urban political agroecology: Rethinking the urbanisms of agroecological transitions for food system transformation. Agroecology and Sustainable Food Systems 44 (5): 594-610.

Valentine, G. 2008. Living with difference: Reflections on geographies of encounter. Progress in Human Geography 32 (3): 323-337.

Publisher's Note Springer Nature remains neutral with regard to jurisdictional claims in published maps and institutional affiliations.

Colleen Hammelman is an assistant professor in the Department of Geography and Earth Sciences at the University of North Carolina at Charlotte. She is a critical urban geographer with a research and teaching focus on social justice in urban food systems across the Americas. You can learn more at https://pages.uncc.edu/colleen-hammelman.

Elizabeth Shoffner is a Ph.D. Candidate in Geography at the University of Washington. Her research examines how the knowledge politics of environmental management impact land struggles in Latin America. She holds a Master Universitario in Agroecology from the Universidad de Córdoba (Spain) and a Bachelor of Science in Architecture from the University of Virginia (USA).

Maria Cruzat earned B.A. degrees in Public Health, International Studies, and Spanish from the University of North Carolina at Charlotte. Her past research centers on global competency development and menstrual knowledge and practices. She is currently working with a non-profit.

Samantha Lee holds a B.A. in International Studies and Spanish from the University of North Carolina at Charlotte. Her past research endeavors include participation in the Youth as Researchers program with UNESCO to analyze the impact of the COVID-19 pandemic on youth worldwide. She currently works in nonprofit marketing. 